\title{
Pengembangan Video Interaktif pada Pembelajaran IPA Tematik Integratif Materi Peredaran Darah Manusia
}

\author{
Ratri Kurnia Wardani ${ }^{1 *}$, Harlinda Syofyan ${ }^{2}$ \\ 1,2.Jurusan Pendidikan Guru Sekolah Dasar (PGSD), Universitas Esa Unggul , Indonesia.
}

\author{
A R T I C L E I N F O \\ Article history: \\ Received 20 August 2018 \\ Received in revised form \\ 9 September 2018 \\ Accepted 15 October 2018 \\ Available online 25 \\ November 2018

\begin{tabular}{l}
\hline Kata Kunci: \\
Pengembangan, video \\
interaktif, IPA Tematik \\
Integratif, peredaran darah \\
manusia \\
Keywords: \\
Development, interactive \\
video, Integrative Thematic \\
Science, human blood \\
circulation
\end{tabular} \\ Kata Kunci: \\ engembangan, video \\ Integratif, peredaran darah \\ manusia \\ Keywords: \\ video, Integrativ \\ circulation
}

\begin{abstract}
A B S T R A K
Penelitian ini bertujuan untuk mengembangkan video interaktif menggunakan aplikasi Adobe Flash CS6 pada pembelajaran IPA Tematik Integratif materi peredaran darah manusia di kelas $V$ sekolah dasar. Jenis penelitian yang digunakan adalah penelitian dan pengembangan (research and development) dengan mengacu pada 9 langkah yang dikembangkan oleh model Dick and Carey. Adapun subjek di dalam penelitian ini adalah siswa kelas VA SDIT Insan Madani yang berjumlah 28 orang. Instrumen yang digunakan berupa lembar angket validasi untuk para ahli (materi, media, bahasa, dan guru), lembar studi pendahuluan untuk siswa, dan angket respon siswa. Teknik pengumpulan data yang digunakan adalah wawancara, kuesioner, dan dokumentasi. Hasil penelitian menunjukkan bahwa media pembelajaran video interaktif memperoleh persentase nilai akhir (NP) dari ketiga pakar sebesar $88,7 \%$ dengan kategori "Sangat Baik". Penilaian dari guru kelas menunjukkan persentase sebesar $85,7 \%$ dengan kategori "Sangat Baik". Penilaian respon peserta didik pada ujicoba satu-satu menunjukkan persentase sebesar $94,8 \%$ dengan
\end{abstract} kategori "Sangat Baik. Penilaian respon peserta didik pada ujicoba kelompok terbatas menunjukkan persentase sebesar 95,3\% dengan kategori "Sangat Baik". Sedangkan penilaian siswa pada ujicoba lapangan menunjukkan persentase sebesar $87,8 \%$ dengan kategori "Sangat Baik". Hasil uji efektifitas media menunjukkan bahwa $t_{\text {hitung }}(6.32)>t_{\text {tabel }}(2,05)$ yang artinya efektif untuk diterapkan di dalam pembelajaran.

\begin{abstract}
A B S T R A C T
This study aims to develop an interactive video using the Adobe Flash CS6 application on Integrative Thematic Science learning on human circulatory material in the fifth grade of elementary school. The type of research used is research and development (research and development) with reference to the 9 steps developed by the Dick and Carey model. The subjects in this study were 28 students of VA class SDIT Insan Madani. The instruments used were in the form of validation questionnaires for experts (material, media, language, and teachers), preliminary study sheets for students, and student response questionnaires. Data collection techniques used were interviews, questionnaires, and documentation. The results showed that interactive video learning media obtained a percentage of the final value (NP) of the three experts by $88.7 \%$ with the category "Very Good". The assessment of class teachers shows a percentage of $85.7 \%$ with the category "Very Good". Assessment of students' responses to the one-on-one trial showed a percentage of $94.8 \%$ with the category "Very Good. Assessment of students' responses to limited group trials showed a percentage of $95.3 \%$ with the category "Very Good". While the assessment of students in field trials showed a percentage of $87.8 \%$ with the category "Very Good". The results of the media effectiveness test show that tcount (6.32)>t table (2.05) which means effective to be applied in learning.
\end{abstract}

Copyright (C) Universitas Pendidikan Ganesha. All rights reserved. 


\section{Pendahuluan}

Kurikulum 2013 merupakan kurikulum terbaru yang saat ini mulai diterapkan di setiap jenjang pendidikan termasuk di Sekolah Dasar. Di dalam Kurikulum 2013, beberapa mata pelajaran dihubungkan menjadi satu dalam sebuah tema sebagai payungnya. Beberapa mata pelajaran tidak lagi tersegmentasi atau terpisah-pisah, namun saling terpadu dalam berbagai tema. Pembelajaran dengan menggabungkan beberapa mata pelajaran ke dalam sebuah tema disebut juga dengan pembelajaran tematik integratif. Di dalam pembelajaran tematik integratif, terjadi pengintegrasian kompetensi-kompetensi dari berbagai mata pelajaran menjadi tema tertentu, sehingga pengalaman yang diperoleh peserta didik akan semakin banyak dan bermakna, serta tidak terbatas pada disiplin ilmu tertentu. Mata pelajaran IPA, IPS, PKN, Matematika, dan Bahasa Indonesia dipelajari dengan tidak tersegmentasi.

Ilmu Pengetahuan Alam (IPA) merupakan salah satu mata pelajaran yang juga terintegrasi dengan mata pelajaran yang lain di dalam Kurikulum 2013. Materi-materi yang ada pada mata pelajaran IPA berisi sejumlah fenomena-fenomena yang terjadi di alam dan hal-hal yang terjadi di dalam tubuh manusia itu sendiri. Mata pelajaran IPA telah diajarkan pada tingkat sekolah dasar. Mata pelajaran ini sangat bermanfaat bagi perkembangan peserta didik kelak. Syofyan (2015:135), memaparkan bahwa mata pelajaran IPA memberikan sumbangsih atau kontribusi bagi proses pendidikan anak dan perkembangan individu pada masa yang akan datang. Lebih lanjut, Syofyan (2015:135), menjelaskan bahwa keterlibatan peserta didik di dalam mengikuti pembelajaran IPA sangat penting karena IPA memberikan ruang bagi peserta didik untuk mengembangkan keterampilan, membuka wawasan, dan memanfaatkan berbagai teknologi yang dapat diterapkan di dalam kehidupan sehari-hari.

Akan tetapi, terdapat beberapa konsep dalam materi IPA yang membutuhkan pemahaman tertentu, sehingga sulit dipahami oleh peserta didik secara langsung karena banyaknya istilah-istilah asing. Hal ini sesuai dengan pendapat yang disampaikan oleh Awang (2015:6), bahwa peserta didik tidak menyukai pelajaran IPA karena sulit dan banyak istilah asing yang tidak mereka pahami. Salah satu materi pada pelajaran IPA yang sulit untuk dipahami adalah materi peredaran darah manusia. Kesulitan ini terjadi karena proses peredaran darah manusia itu sendiri sulit untuk dilihat secara langsung jika tidak menggunakan suatu media pembelajaran, serta proses yang terjadi di dalam tubuh tersebut terjadi sangat cepat atau lambat. Hal ini didukung dengan pernyataan yang disampaikan oleh Nicolas, dkk (2015:1), bahwa materi peredaran darah sulit dijelaskan secara oral karena prosesnya berjalan terlalu cepat atau terlalu lambat.

Berdasarkan analisis hasil ulangan harian IPA peserta didik kelas VA SD IT Insan Madani, diperoleh informasi bahwa 75\% peserta didik mendapatkan nilai di bawah Kriteria Ketuntasan Minimal (KKM). Data tersebut relevan dengan hasil analisis angket studi pendahuluan peserta didik yang disebar pada tanggal 12 April 2018, yang menunjukkan bahwa 80\% peserta didik mengalami kesulitan di dalam memahami materi peredaran darah manusia. Akan tetapi, sebanyak $90 \%$ peserta didik memiliki ketertarikan untuk belajar materi peredaran darah manusia. Dengan kata lain, hanya 10\% peserta didik yang tidak tertarik dengan materi peredaran darah manusia. Dari hasil analisis angket tersebut, juga diperoleh informasi bahwa sebanyak $90 \%$ peserta didik merasa senang mempelajari materi peredaran darah manusia. Hanya saja, guru kelas VA masih menggunakan metode ceramah untuk menjelaskan materi tentang peredaran darah manusia. Akibatnya, sebanyak 80\% merasa bosan dalam mengikuti pembelajaran.

Persentase hasil analisis angket studi pendahuluan peserta didik SD IT Insan Madani pada materi peredaran darah manusia dapat dibuat dalam bentuk diagram batang pada gambar 1 berikut ini:

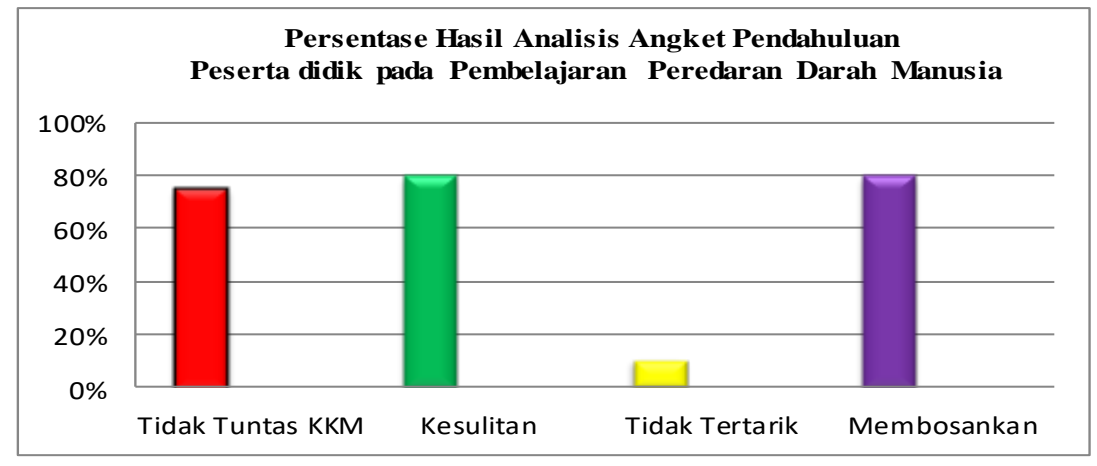

Gambar 1. Persentase Hasil Analisis Angket Pendahuluan Peserta Didik 
Berdasarkan uraian masalah di atas, perlu adanya suatu media pembelajaran yang menarik dan interaktif agar peserta didik termotivasi dan terlibat secara langsung di dalam proses pembelajaran ketika mempelajari materi peredaran darah manusia. Hal ini sesuai dengan pernyataan yang disampaikan oleh Syofyan dan Ismail (2018), bahwa perangkat pembelajaran yang dihadirkan perlu sebaiknya mampu meningkatkan kemampuan berpikir kritis peserta didik, khususnya pada mata pelajaran IPA. Media pembelajaran yang dibutuhkan perlu untuk didesain terlebih dahulu (by design) karena media pembelajaran yang interaktif belum pernah digunakan oleh guru kelas. Selain itu, media pembelajaran yang dikembangkan harus disesuaikan dengan karakteristik peserta didik kelas VA SDIT Insan Madani. Sehingga, tujuan dari pembelajaran dapat tercapai dengan tetap menempatkan keberagaman karakteristik peserta didik sebagai poin utama. Alasan lain perlunya mendesain sendiri media pembelajaran yang akan digunakan adalah mahalnya harga media pembelajaran interaktif di lapangan. Sehingga, untuk meminimalisir pengeluaran biaya, maka peneliti mengembangkan sendiri media pembelajaran interaktif yang dimaksud. Meskipun waktu yang diperlukan untuk mengembangkan media pembelajaran jenis ini cukup lama, namun diharapkan media pembelajaran ini dapat membantu peserta didik untuk lebih mudah memahami materi peredaran darah manusia dan membuat mereka menjadi lebih aktif jika dibandingkan ketika guru menggunakan media pembelajaran berupa gambar saja (visual).

Pengembangan media pembelajaran interaktif ini relevan dengan hasil analisis angket studi pendahuluan peserta didik yang menunjukkan bahwa $90 \%$ peserta didik menginginkan adanya media pembelajaran yang dapat melibatkan mereka secara langsung dan sebanyak $80 \%$ peserta didik akan termotivasi jika belajar menggunakan video pembelajaran yang menarik dan interaktif. Salah satu media yang dapat meningkatkan minat dan motivasi peserta didik, serta melibatkan mereka secara aktif di dalam mempelajari materi peredaran darah manusia adalah media pembelajaran multimedia berupa video interaktif yang dibuat menggunakan aplikasi Adobe Flash CS6. Pemilihan Adobe Flash CS6 sebagai salah satu aplikasi yang digunakan untuk membuat video interaktif didasarkan atas pertimbangan bahwa Adobe Flash CS6 dapat digunakan untuk membuat tema, latar belakang, karakter tokoh, dan konten yang dapat disesuaikan dengan kebutuhan pembelajaran. Selain itu, aplikasi ini juga mendukung untuk membuat sebuah video yang menyediakan tombol navigasi. Sehingga, peserta didik dapat berinteraksi secara langsung dengan media pembelajaran yang digunakan.

Video interaktif adalah media pembelajaran yang di dalamnya mengkombinasikan unsur suara, gerak, gambar, teks, ataupun grafik yang bersifat interaktif untuk menghubungkan media pembelajaran tersebut dengan penggunanya (Prastowo, 2014:370) ${ }^{[5]}$. Pengertian lain dijelaskan oleh Niswa, $(2012: 3)^{[6]}$, bahwa: Video interaktif berisi tuntunan praktis secara tepat sasaran, disajikan lewat presentasi audio visual (gambar dan suara) yang dilengkapi dengan suara penuntun berbahasa Indonesia yang jelas dan mudah dipahami dan dikemas dalam program autorun, sehingga dengan cd interaktif siswa dapat belajar secara mandiri setiap saat dan akan sangat menunjang bagi pendalaman materi. Di dalam video interaktif, terjadi interaksi atau hubungan timbal balik antara pengguna dengan media itu sendiri. Hal ini sesuai dengan pernyataan yang disampaikan oleh Yasa, dkk., (2017:201)[7], bahwa suatu media dikatakan interaktif apabila terjadi keterlibatan antara peserta didik dengan media tersebut, sehingga peserta didik tidak hanya sekedar melihat atau mendengarkan materi di dalam media tersebut saja. Salah satu komponen penting yang harus ada di dalam video interaktif adalah perangkat komputer. Komputer digunakan secara terintegrasi di dalam pembelajaran. Dengan demikian, akan terjadi interaksi antara pengguna dengan komputer tersebut. Dalam hal ini, komputer berperan sebagai media yang dapat membantu guru di dalam menjelaskan materi pembelajaran (Priyanto, 2009:3) [8]. Selain itu, komputer juga digunakan sebagai pembuat program aplikasi untuk video yang sedang dikembangkan, sekaligus sebagai alat untuk menayangkan hasil akhir video yang telah dibuat.

Suparman (2014:90), menyatakan bahwa desain pembelajaran merupakan kombinasi antara ilmu dan seni yang bertujuan untuk menciptakan suatu sistem pembelajaran yang berkualitas melalui berbagai macam proses, seperti: analitik, sistematik, sistemik, efektif dan efisien sehingga tujuan pembelajaran tercapai dengan baik, sehingga dapat mengatasi kesenjangan keadaan hasil belajar. Pendapat lain juga disampaikan oleh Yaumi (2013:17), yang menjelaskan desain pembelajaran sebagai serangkaian langkah yang terorganisasi, yang meliputi: (1) menganalisis; (2) merancang; (3) mengembangkan; (4) mengaplikasikan; dan (5) menilai pembelajaran. Mudlofir \& Evi (2017:34), juga menjelaskan tentang desain pembelajaran sebagai langkah-langkah kerja di dalam kegiatan pembelajaran dengan tujuan agar proses pembelajaran dan output yang dihasilkan dapat tercapai dengan baik. Salah satu model desain pembelajaran yang digunakan di dalam pendidikan adalah model Dick \& Carey. Hal ini sesuai dengan pendapat yang disampaikan oleh Trianto (2014:222), yang menyatakan bahwa tiga model desain pembelajaran yang digunakan dalam pengembangan perangkat pembelajaran adalah model Dick\&Carey, model Four-D, dan model Kemp. Mudlofir \& Evi (2017:56-58), menjelaskan sepuluh tahapan atau langkah-langkah desain pembelajaran menurut model Dick \& Carey sebagai berikut: (1) mengidentifikasi 
tujuan pembelajaran; (2) melakukan analisis pembelajaran; (3) mengidentifikasi perilaku awal dan karakteristik; (4) merumuskan tujuan pembelajaran; (5) mengembangkan butir tes acuan kriteria; (6) mengembangkan strategi pembelajaran; (7) mengembangkan dan memilih bahan pembelajaran; (8)merancang dan melakukan evaluasi formatif; (9) merevisi pembelajaran; dan (10) melakukan evaluasi sumatif.

Berdasarkan uraian di atas, maka penulis tertarik untuk mengembangkan video pembelajaran interaktif pada materi peredaran darah manusia yang disesuaikan dengan Kurikulum 2013 yang saat ini diterapkan di SDIT Insan Madani. Sehingga, diharapkan video interaktif tersebut dapat memudahkan peserta didik untuk memahami materi peredaran darah manusia dan melibatkan mereka secara aktif di dalam pembelajaran.

\section{Metode}

Metode yang digunakan di dalam penelitian ini adalah penelitian dan pengembangan atau Research and Development (R\&D). Sugiyono (2016:407), menjelaskan bahwa penelitian dan pengembangan atau R\&D (Research and Development) merupakan metode penelitian yang bertujuan untuk menghasilkan suatu produk tertentu, kemudian menguji keefektifitasannya. Video interaktif sebagai produk yang dihasilkan, dikembangkan dengan model desain pembelajaran Dick \& Carey. Adapun langkah-langkah model Dick \& Carey adalah: (1) tahap analisis kebutuhan; (2) tahap analisis pembelajaran; (3) tahap analisis pembelajar dan konteks; (4) tahap merumuskan tujuan khusus pembelajaran; (5) tahap mengembangkan instrumen penilaian; (6) tahap pemilihan strategi pembelajaran; (7) tahap memilih dan mengembangkan bahan ajar; (8) tahap penilaian formatif; (9)dan tahap revisi pembelajaran.

Pengembangan media pembelajaran berupa video interaktif ini dilakukan dengan serangkaian kegiatan uji coba yang meliputi: ujicoba ahli, ujicoba satu-satu dengan peserta didik, ujicoba terbatas, dan ujicoba lapangan. Adapun subjek di dalam penelitian ini adalah ahli materi, ahli media, ahli bahasa, guru kelas, dan peserta didik kelas VA SDIT Insan Madani. Teknik pengumpulan data yang digunakan adalah wawancara, penyebaran angket, dan dokumentasi. Instrumen pengumpulan data yang digunakan meliputi: angket studi pendahuluan peserta didik, angket penilaian para ahli, dan angket respon siswa.

Penelitian ini menggunakan teknik analisis data berupa uji validitas produk, uji respon siswa, dan pengitungan nilai pretest dan postest. Data uji validitas produk diperoleh dari hasil penilaian para ahli. Tujuan dari uji validitas produk ini adalah untuk mengukur valid atau tidaknya media pembelajaran yang dikembangkan. Untuk mengukur validitas media pembelajaran ini, digunakan rumus (Purwanto, 2013:102):

$\begin{array}{ll}\mathrm{NP} & =\text { Nilai persentase kelayakan } \\ \mathrm{R} & =\text { Jumlah skor yang diperoleh } \\ \mathrm{SM} & =\text { Jumlah skor maksimum } \\ 100 \% & =\text { Bilangan Tetap }\end{array}$

Selanjutnya, digunakan tabel kriteria uji kelayakan media sebagai berikut.

Tabel 1. Kriteria Uji Kelayakan Media

\begin{tabular}{cc}
\hline Presentase (\%) & Interpretasi \\
\hline $81-100$ & Sangat Baik/Sangat Layak \\
$61-80$ & Baik/Layak \\
$41-60$ & Cukup Baik/Cukup Layak \\
$21-40$ & Kurang Baik/Kurang Layak \\
$0-20$ & Tidak Baik/ Tidak Layak \\
\hline & (Sumber: Arikunto \& Jabar, 2009:35)
\end{tabular}

Untuk menghitung nilai pretest dan postest menggunakan rumus yang dijelaskan oleh Sudijono (2016:305-406) [17]:

$$
\begin{aligned}
& \mathrm{MD}=\frac{\mathbb{E D}}{\mathbb{N}} \\
& \mathrm{SE}=\frac{\mathrm{SD}}{\sqrt{\mathrm{N}-1}}
\end{aligned}
$$$$
\mathbf{T}_{\text {hitung }}=\frac{\text { MD }}{\mathrm{SE}}
$$ 
$\mathrm{SD}=\sqrt{\left(\frac{\mathbb{N D}}{\mathrm{N}}\right)-\left(\frac{\mathbb{D}}{\mathrm{N}}\right)^{2}}$

Keterangan:

MD = Nilai rata-rata hitung dari selisih skor variabel $\mathrm{X}$ dan variabel $\mathrm{Y}$

SE = Standard Error (standar kesalahan)

SD = Standar deviasi

$\Sigma \mathrm{D} \quad=$ Jumlah beda antara skor variabel $\mathrm{X}$ dan skor variabel $\mathrm{Y}$

$\mathrm{N}=$ Number of Case

\section{Hasil dan Pembahasan}

Video interaktif pada pembelajaran IPA Tematik Integratif materi peredaran darah manusia untuk kelas V SDIT Insan Madani. Video interaktif yang dikembangkan dibuat dengan menggunakan aplikasi Adobe Flash CS6. Tim Madcoms (2006) dalam Wibowo (2013), menyatakan bahwa Adobe Flash CS6 merupakan sebuah program animasi yang sudah banyak digunakan oleh para pembuat animasi (animator). Aplikasi Adobe Flash CS6 digunakan para animator untuk membuat animasi interaktif maupun non interaktif, seperti animasi pada halaman web, animasi kartun, presentasi, portofolio sebuah perusahaan, game dan beberapa media animasi lainnya.

Keunggulan program Adobe Flash Professional CS6 dibandingkan dengan program lain yang sejenis, antara lain : 1) Mampu membuat tombol interakif dengan sebuah movie atau objek yang lain, 2) Mampu membuat perubahan transparansi warna dalam movie, 3) Mampu membuat perubahan animasi dari satu bentuk ke bentuk lain, 4) Mampu membuat gerakan animasi dengan mengikuti alur yang telah ditetapkan.

Adapun komponen-komponen di dalam video interaktif yang dikembangkan secara lebih rinci diuraikan sebagai berikut.

\section{Halaman Pembuka}

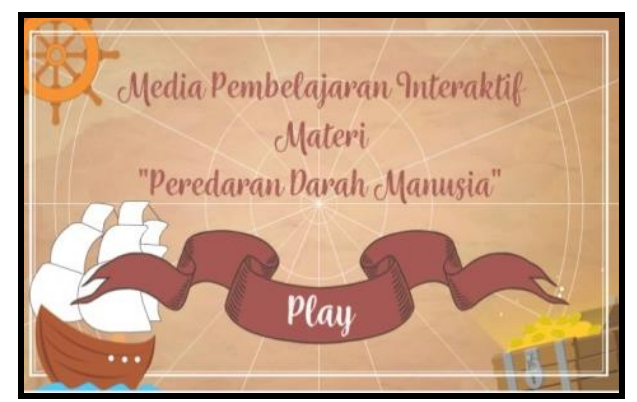

3. Halaman Do'a Pembuka

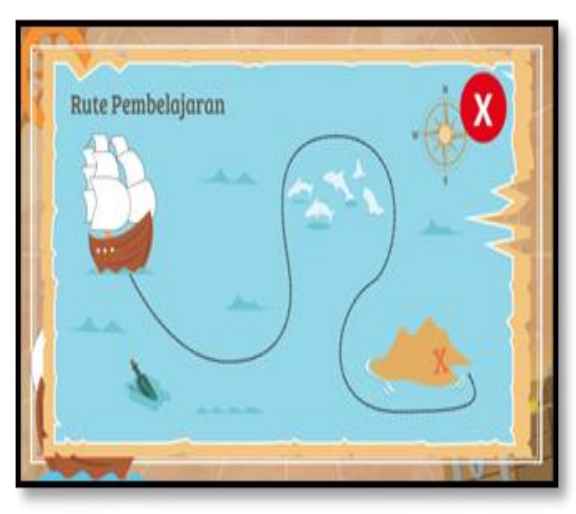

\section{Halaman Perkenalan}

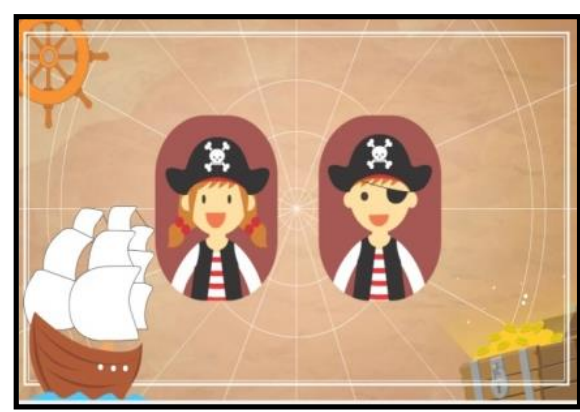

4. Halaman Indikator

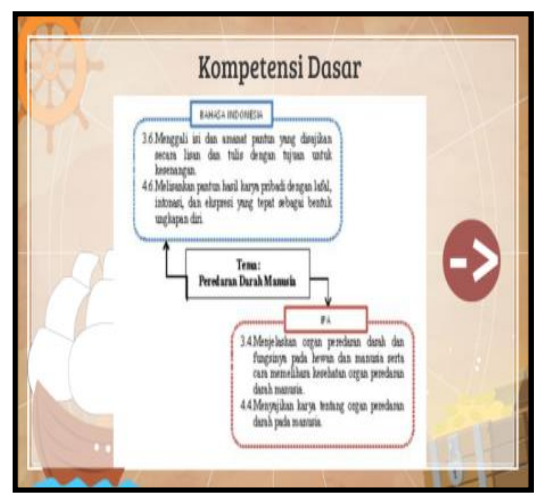


1. Halaman Materi

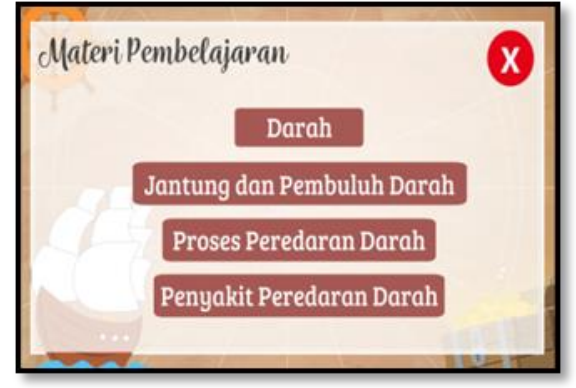

7. Halaman Penutup

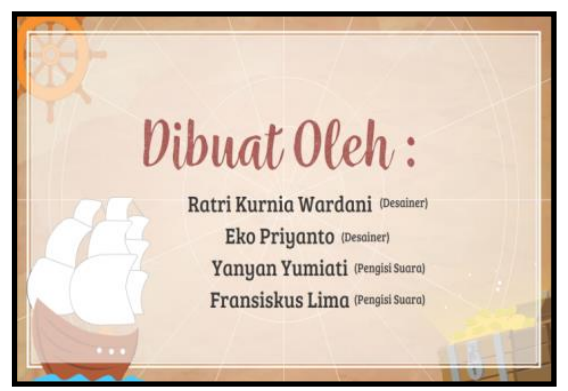

6. Halaman Kuis
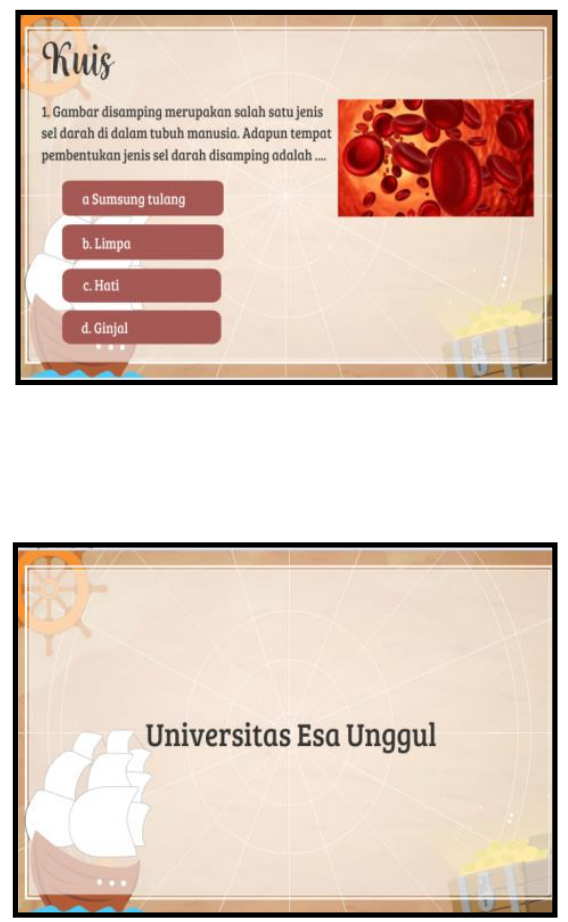

Untuk menguji kelayakan dari media pembelajaran yang dikembangkan, maka dilakukan beberapa ujicoba. Adapun hasil penilaian dari ujicoba yang dilakukan adalah sebagai berikut.

a. Penilaian oleh Para Ahli

Penilaian media oleh para ahli. Hasil penilaian yang diberikan oleh ahli materi, ahli media, dan ahli bahasa terhadap media pembelajaran video interaktif pada pemelajaran tematik integratif materi peredaran darah manusia adalah sebagai berikut.

Tabel 2. Akumulasi Persentase Penilaian Para Ahli

\begin{tabular}{|c|c|c|c|}
\hline No & Validator & Persentase $(\%)$ & Keterangan \\
\hline 1. & Ahli Materi & 81 & Sangat Baik \\
\hline 3. & Ahli Media & 96 & Sangat Baik \\
\hline \multirow[t]{3}{*}{5.} & Ahli Bahasa & 89 & Sangat Baik \\
\hline & ah & 266 & \\
\hline & rata & $\mathbf{8 8 , 7}$ & Sangat Baik \\
\hline
\end{tabular}

Berdasarkan tabel di atas, diketahui bahwa hasil penilaian yang diberikan oleh ahli materi adalah sebesar 81\% dengan kriteria "Sangat Baik". Hasil penilaian dari ahli media adalah sebesar 96\% dengan kriteria "Sangat Baik". Sementara penilaian yang diperoleh dari ahli bahasa adalah sebesar 89\% dengan kriteria "Sangat Baik". Jika diakumulasikan dari ketiga ahli, maka besarnya persentase yang diperoleh untuk penilaian media pembelajaran video interaktif adalah sebesar 88,7\% dengan kriteria "Sangat Baik". Dengan demikian, media pembelajaran yang dikembangkan sudah dapat digunakan di dalam pembelajaran namun masih perlu dilakukan revisi (perbaikan). Berikut ini adalah saran perbaikan yang diberikan oleh para ahli.

Tabel 3. Saran Perbaikan Ahli Materi

\begin{tabular}{cl}
\hline No & \multicolumn{1}{c}{ Komentar dan Saran } \\
\hline 1. & Memperbaiki kesalahan-kesalahan pengetikan pada beberapa halaman. \\
2. & Menambahkan nama-nama pengisi suara pada halaman penutup. \\
\hline
\end{tabular}


Tabel 4. Saran Perbaikan Ahli Media

No

1.

2.
Komentar dan Saran

Memperjelas media semiotika (tanda dan penanda). Dalam hal ini, perlu memperbaiki simbol close atau keluar pada video interaktif. Sehingga, mempermudah peserta didik untuk mengenalinya. Pada video interaktif sebelum dilakukan perbaikan, tombol keluar pada media kurang jelas untuk dipahami oleh peserta didik.

Memperbaiki penggunaan huruf dan gambar agar lebih mudah dan jelas terlihat oleh peserta didik. Sebelum dilakukan perbaikan, huruf atau font yang digunakan sulit untuk dilihat secara jelas oleh peserta didik karena menggunakan jenis huruf tegak bersambung, sementara gambar yang disajikan terlalu kecil.

Tabel 5. Saran Perbaikan Ahli Bahasa

\begin{tabular}{cl}
\hline No & \multicolumn{1}{c}{ Komentar dan Saran } \\
\hline 1. & $\begin{array}{l}\text { Memperbaiki tata bahasa yang digunakan di dalam media pembelajaran agar } \\
\text { lebih baik lagi. }\end{array}$ \\
2. & $\begin{array}{l}\text { Tambahkan nomor pada setiap soal (kuis) agar peserta didik lebih mudah } \\
\text { mengingat nomor soal yang menurut mereka sulit. }\end{array}$ \\
3. & Diksi yang digunakan lebih bervariasi agar peserta didik tidak bosan. \\
\hline
\end{tabular}

b. Penilaian oleh Guru Kelas

Setelah dilakukan penilaian oleh para ahli, selanjutnya media pembelajaran yang dikembangkan juga dinilai oleh guru kelas. Penilaian oleh guru kelas penting untuk dilakukan karena guru kelas merupakan salah satu pihak yang akan menggunakan media tersebut di dalam pembelajaran. Berikut adalah tabel yang menunjukkan hasil penilaian yang dilakukan oleh guru, yang meliputi aspek materi, media, dan bahasa.

Tabel 6. Akumulasi Penilaian Guru Kelas

\begin{tabular}{ccc}
\hline No & Aspek Penilaian & Persentase (\%) \\
\hline 1. & Materi & 85,5 \\
2. & Media & 82,6 \\
3. & Bahasa & 83,6 \\
& Jumlah & $\mathbf{2 5 1 , 7}$ \\
& Rata-rata & $\mathbf{8 3 , 9}$ \\
\hline
\end{tabular}

Dari hasil akumulasi penilaian yang dilakukan oleh guru kelas, diperoleh persentase rata-rata sebesar 83,9\%. Besarnya persentase ini menunjukkan bahwa media pembelajaran video interaktif pada materi peredaran darah manusia termasuk ke dalam kategori "Sangat Baik" atau "Sangat Layak" untuk digunakan sebagai media di dalam proses pembelajaran. Pada tahap penilaian yang dilakukan oleh guru kelas, tidak ada perbaikan lagi terhadap media yang dikembangkan.

\section{c. Uji Satu-satu oleh Peserta Didik}

Produk yang telah dikembangkan diujicobakan pada 3 orang peserta didik kelas VA yang dipilih secara random. Kegiatan ujicoba satu-satu oleh peserta didik dilakukan pada hari Rabu, 29 Agustus 2018. Di dalam tahap ini, 3 orang peserta didik yang telah dipilih secara random diminta untuk melihat tayangan materi peredaran darah manusia pada video interaktif. Selanjutnya, mereka diberikan angket untuk memberikan penilaian terhadap media pembelajaran tersebut.

Adapun hasil penilaian ujicoba dari 3 orang peserta didik dijabarkan dalam Tabel berikut. 
Tabel 7. Hasil Pengolahan Angket Ujicoba Satu-satu Dengan Peserta Didik

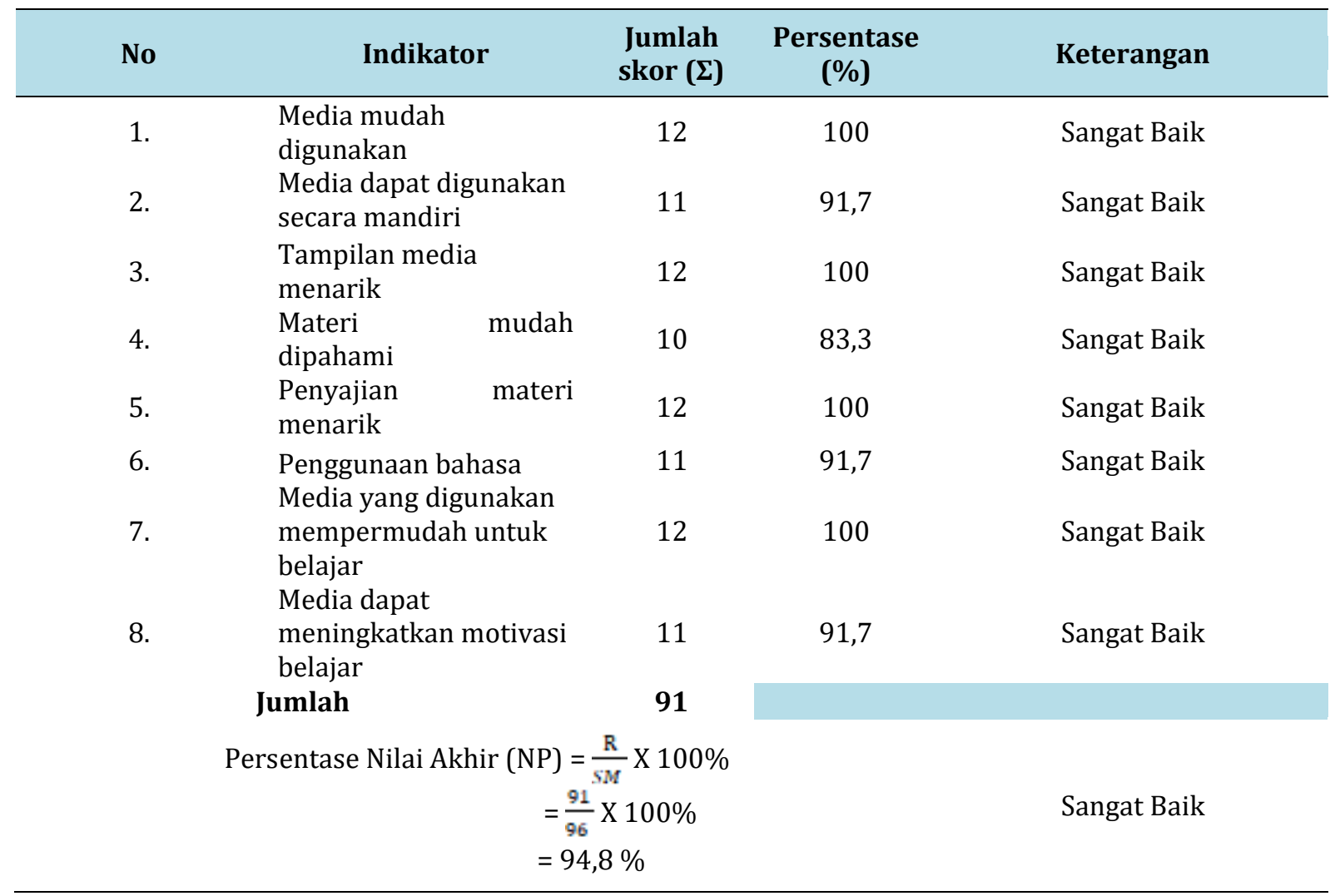

Berdasarkan tabel di atas, penilaian ketiga peserta didik terhadap media pembelajaran video interaktif menunjukkan angka persentase sebesar 94,8\%. Dengan mengacu pada tabel kriteria kelayakan media menurut Arikunto \& Jabar (2009:35), video interaktif yang dikembangkan menunjukkan kriteria "Sangat Baik" untuk digunakan di dalam pembelajaran.

d. Uji Kelompok Terbatas

Pada tahap ini, 10 orang peserta didik dari kelas VA dipilih secara random untuk melihat tayangan materi peredaran darah manusia pada video interaktif yang dikembangkan. Selanjutnya, kesepuluh responden diberikan angket untuk memberikan penilaian terhadap media pembelajaran tersebut. Adapun hasil penilaian ujicoba dari 10 orang peserta didik dijabarkan dalam tabel berikut.

Tabel 8. Hasil Pengolahan Angket Ujicoba Kelompok Terbatas

\begin{tabular}{|c|c|c|c|c|}
\hline No & Indikator & Jumlah skor $(\Sigma)$ & Persentase (\%) & Keterangan \\
\hline 1. & Media mudah digunakan & 37 & 92,5 & Sangat Baik \\
\hline 2. & Media dapat digunakan secara mandiri & 37 & 92,5 & Sangat Baik \\
\hline 3. & Tampilan media menarik & 40 & 100 & Sangat Baik \\
\hline 4. & Materi mudah dipahami & 35 & 87,5 & Sangat Baik \\
\hline 5. & Penyajian materi menarik & 40 & 100 & Sangat Baik \\
\hline 6. & Penggunaan bahasa & 38 & 95 & Sangat Baik \\
\hline 7. & $\begin{array}{l}\text { Media yang digunakan mempermudah } \\
\text { untuk belajar }\end{array}$ & 39 & 97,5 & Sangat Baik \\
\hline \multirow[t]{2}{*}{8.} & $\begin{array}{l}\text { Media dapat meningkatkan motivasi } \\
\text { belajar }\end{array}$ & 39 & 97,5 & Sangat Baik \\
\hline & Jumlah & 305 & & \\
\hline
\end{tabular}




$$
\begin{aligned}
\text { Persentase Nilai Akhir (NP) } & =\frac{\mathrm{R}}{S M} \times 100 \% \\
= & \frac{305}{320} \times 100 \% \\
= & 95,3 \%
\end{aligned}
$$

Pada ujicoba kelompok terbatas, media pembelajaran video interaktif memperoleh persentase nilai akhir dari sepuluh responden yakni sebesar 95,3\%. Dengan mengacu pada konversi data kuantitatif ke kualitatif, maka video interaktif ini masih ke dalam kategori "Sangat Baik". Dalam hal ini, media pembelajaran yang dikembangkan sudah siap untuk diterapkan di dalam pembelajaran.

\section{e. Uji Lapangan}

Pada tahap akhir dilakukanlah ujicoba lapangan. Adapun peserta didik yang diikutsertakan dalam

\begin{tabular}{|c|c|c|c|c|}
\hline No & Indikator & Jumlah skor $(\Sigma)$ & Persentase (\%) & Keterangan \\
\hline 1. & Media mudah digunakan & 107 & 95,5 & Sangat Baik \\
\hline 2. & Media dapat digunakan secara mandiri & 90 & 80,3 & Baik \\
\hline 3. & Tampilan media menarik & 98 & 87,5 & Sangat Baik \\
\hline 4. & Materi mudah dipahami & 101 & 90,1 & Sangat Baik \\
\hline 5. & Penyajian materi menarik & 96 & 85,7 & Sangat Baik \\
\hline 6. & Penggunaan bahasa & 92 & 82,1 & Sangat Baik \\
\hline 7. & $\begin{array}{l}\text { Media yang digunakan mempermudah } \\
\text { untuk belajar }\end{array}$ & 101 & 90,1 & Sangat Baik \\
\hline \multirow[t]{3}{*}{8.} & $\begin{array}{l}\text { Media dapat meningkatkan motivasi } \\
\text { belajar }\end{array}$ & 102 & 91 & Sangat Baik \\
\hline & Jumlah & 787 & & \\
\hline & Persentase Nilai Akhir ( & $\begin{array}{l}\text { IP) }=\frac{\mathrm{R}}{\mathrm{SM}} \times 100 \% \\
=\frac{787}{896} \times 100 \% \\
=87,8 \%\end{array}$ & & Sangat Baik \\
\hline
\end{tabular}
tahap ujicoba lapangan adalah seluruh peserta didik kelas VA yang berjumlah 28 orang. Berdasarkan uji lapangan yang telah dilakukan, diperoleh data dari dari keduapuluh delapan peserta didik sebagai berikut.

Tabel 9. Hasil Pengolahan Angket Ujicoba Lapangan

Berdasarkan data pada tabel di atas, persentase nilai akhir yang diperoleh dari hasil angket respon siswa pada uji lapangan adalah sebesar 87,8\%. Dengan mengacu pada konversi data kuantitatif ke kualitatif, maka video interaktif ini masih ke dalam kategori "Sangat Baik".

Pada tahap terakhir, dilakukan penghitungan hasil nilai pretest dan postest untuk mengetahui apakah terdapat perbedaan hasil belajar peserta didik pada materi peredaran darah manusia ketika sebelum menggunakan media pembelajaran berupa video interaktif dengan setelah menggunakan media pembelajaran tersebut. Penghitungan hasil nilai pretest dan postest dilakukan dengan menggunakan rumus yang dijelaskan oleh Sudijono.

Adapun penghitungannya dapat dilihat dalam Tabel di bawah ini.

Tabel 10. Perhitungan Nilai Hasil Pretest dan Postest Pada Uji Coba Lapangan

\begin{tabular}{ccccc}
\hline Responden & $\mathbf{X}$ & $\mathbf{Y}$ & $\mathbf{D}=\mathbf{( X - Y )}$ & $\mathbf{D}^{\mathbf{2}}$ \\
\hline 1 & 45 & 50 & -5 & 25 \\
2 & 45 & 60 & -15 & 225 \\
3 & 35 & 40 & -5 & 25 \\
4 & 40 & 45 & -5 & 25 \\
5 & 40 & 70 & -30 & 900 \\
6 & 25 & 45 & -20 & 400 \\
7 & 20 & 30 & -10 & 100 \\
\hline
\end{tabular}




\begin{tabular}{ccccc}
\hline 8 & 20 & 35 & -15 & 225 \\
9 & 25 & 30 & -5 & 25 \\
10 & 40 & 55 & -15 & 225 \\
11 & 50 & 55 & -5 & 25 \\
12 & 45 & 60 & -15 & 225 \\
13 & 40 & 60 & -20 & 400 \\
14 & 30 & 55 & -25 & 625 \\
15 & 50 & 65 & -15 & 225 \\
16 & 15 & 55 & -40 & 1600 \\
17 & 55 & 65 & -10 & 100 \\
18 & 35 & 40 & -5 & 25 \\
19 & 45 & 45 & 0 & 0 \\
20 & 45 & 65 & -20 & 400 \\
21 & 70 & 70 & 0 & 0 \\
22 & 45 & 55 & -10 & 0 \\
23 & 55 & 55 & 0 & 900 \\
24 & 20 & 50 & -30 & 25 \\
25 & 45 & 50 & -5 & 100 \\
26 & 35 & 45 & -10 & 25 \\
27 & 60 & 65 & -5 & 0 \\
28 & 65 & 65 & 0 & 6.950 \\
$28=\mathrm{N}$ & & & -340 & $\sum \mathrm{D}^{2}$ \\
\hline
\end{tabular}

Dengan menggunakan taraf signifikansi sebesar 5\% dan besarnya derajat kesalahan dihitung dengan $\mathrm{df}$ atau $\mathrm{db}=\mathrm{N}-1=28-1=27$, maka:

$$
\begin{array}{ll}
\mathbf{t}_{\text {tabel }} & =2,05 \\
\mathbf{t}_{\text {hitung }} & =6,32
\end{array}
$$

Berdasarkan data hasil perhitungan di atas, bahwa nilai $t_{\text {hitung }}>t_{\text {tabel }}$ yakni $6,32>2,05$, maka Ho ditolak dan Ha diterima. Artinya, terdapat perbedaan pada hasil belajar peserta didik kelas VA SDIT Insan Madani antara sebelum dan sesudah menggunakan media pembelajaran video interaktif pada materi peredaran darah manusia. Dengan demikian, dapat dikatakan bahwa media pembelajaran video interaktif memiliki efektifitas yang baik untuk diterapkan di dalam pembelajaran.

\section{Simpulan dan Saran}

Berdasarkan hasil penelitian dan pembahasan pada bab sebelumnya, maka dapat disimpulkan: Penelitian ini merupakan jenis penelitian dan pengembangan (Research and Development) dengan menggunakan model pengembangan Dick and Carey. Model pengembangan ini terdiri dari sepuluh langkah yang sistematis. Akan tetapi, pada penelitian ini peneliti hanya melaksanakan hingga pada langkah kesembilan. Adapun kesembilan langkah penelitian menurut model Dick and Carey meliputi: (1) mengidentifikasi kebutuhan pembelajaran dan tujuan pembelajaran; (2) melakukan analisis pembelajaran; (3) melakukan analisis pembelajar dan konteks; (4) menuliskan tujuan khusus yang lebih spesifik; (5) mengembangkan butir tes acuan kriteria; (6) mengembangkan strategi pembelajaran; (7) mengembangkan dan memilih bahan ajar; (8) merancang dan melakukan evaluasi formatif; dan (9) melakukan revisi. Adapun kelebihan dari media pembelajaran video interaktif yang dibuat dengan aplikasi Adobe Flas CS6 antara lain: hemat biaya, lebih menarik dan tersedianya tombol navigasi untuk digunakan oleh peserta didik. Sementara kelemahan dari media pembelajaran ini adalah waktu yang diperlukan untuk mengembangkannya cukup lama. Media pembelajaran video interaktif yang dikembangkan memiliki efektifitas yang baik di dalam pembelajaran. Hal ini dibuktikan dengan hasil uji t yang menunjukkan bahwa $t_{\text {hitung }}>t_{\text {tabel }}$.

Berdasarkan hasil penelitian, pembahasan, dan kesimpulan di atas, maka terdapat saran-saran yang dapat diajukan sebagai berikut. 1) Bagi Guru, pada saat menjelaskan materi peredaran darah manusia, diharapkan guru menggunakan media-media pembelajaran yang dapat memvisualisasikan materi tersebut secara lebih konkret, sehingga dapat membantu peserta didik untuk memahami materi tersebut dengan lebih mudah. Selain itu, keterlibatan peserta didik secara aktif juga penting untuk diperhatikan. Salah satu media pembelajaran yang dapat digunakan adalah berupa video interaktif. Di dalam menggunakan video interaktif ini di dalam pembelajaran, sebaiknya guru senantiasa memberikan 
pendampingan kepada peserta didik. Selain itu, guru sebaiknya mempersiapkan komponen-komponen pendukung seperti: laptop, proyektor, dan speaker secara matang, sehingga segala bentuk kendala yang mungkin akan dihadapi dapat diminimalisir. 2) Bagi Peneliti Lain, Bagi peneliti lain yang ingin melakukan penelitian lanjutan atau penelitian sejenis dengan media pembelajaran video interaktif pada materi peredaran darah manusia, sebaiknya memperhatikan tampilan media khsususnya dalam penggunaan animasi agar lebih menarik dan menyenangkan.

\section{Daftar Rujukan}

Awang, I. (2015). Kesulitan Belajar IPA Peserta Didik Sekolah Dasar. Vox Edukasi, 1-17.

Mudlofir, Ali \& Evi Fatimatur, R. (2017). Desain Pembelajaran Inovatif dari Teori ke Praktik. Depok : Rajagrafindo Persada.

Nicolas, Y.,dkk. (2015). Media Interaktif Pembelajaran Sistem Peredaran Darah Manusia. Jurnal Infra.1-6

Niswa, A. (2010). Pengembangan Bahan Ajar Mendengarkan Berbasis Video Interaktif Bermedia Flash Kelas VIID SMP Negeri 1 Kedamean. Jurnal Bahasa Dan Sastra Indonesia, Vol 1, No 1, 1-18.

Purwanto, Ngalim. (2013). Prinsip-prinsip dan Teknik Evaluasi Pembelajaran. Bandung : PT Remaja Rosdakarya.

Prastowo, Andi. (2014) Pengembangan Bahan Ajar Tematik Tinjauan Teoritis dan Praktik. Jakarta :Prenadamedia Group.

Priyanto, D. (2009). Pengembangan Multimedia Pembelajaran Berbasis Komputer. Insania, Vol 14, No 1, $1-13$.

Suparman, Atwi. (2014). Desain Instruksional Modern. Jakarta : Erlangga.

Sugiyono. (2016). Metode Penelitian Pendidikan Pendekatan Kuantitatif, Kualitatif, dan RnD. Bandung : Alfabeta.

Suharsimi , Arikunto \& Jabar, Cepi S.A. (2009). Evaluasi Program Pendidikan. Jakarta : PT Bumi Aksara.

Sudijono.(2015). Pengantar Statistik Pendidikan. Depok : PT.Rajagrafindo Persada.

Syofyan, H \& Ismail, I. (2018). Pembelajaran Inovatif dan Interaktif Dalam Pembelajaran IPA. Jurnal Qhordul Hasan, Vol. 4, No. 1

Syofyan, H. (2015). Peningkatan Hasil Belajar IPA Siswa Kelas V Melalui Metode Resitasi di SD Al Azhar Syifa Budi Jakarta Selatan. Jurnal Pendidikan Dasar, Vol 6, No 1,134-150.

Trianto. (2015). Desain Pengembangan Pembelajaran Tematik Bagi Anak Usia Dini TK/RA \& Anak Kelas Awal SD/MI Implementasi Kurikulum 2013. Jakarta : Prenadamedia Group.

Yasa, K. A., dkk. (2017). Pengembangan Media Pembelajaran Interaktif Berbasis Adobe Flash pada Mata Pelajaran Prakarya dan Kewirausahaan Materi Elektro Listrik untuk Kelas XI MIPA dan IPS di SMA Negeri 3 Singaraja. Jurnal Pendidikan Teknologi Dan Kejuruan, Vol 14, No 2, 199-209.

Yaumi, Muhammad. (2013). Prinsip-prinsip Desain Pembelajaran Disesuaikan dengan Kurikulum 2013. Jakarta : Prenadamedia Group.

Wibowo, J. E. (2013). Media Pembelajaran Interaktif Matematika untuk Siswa Sekolah Dasar Kelas IV. Makalah disampaikan dalam Seminar Riset Unggulan Nasional Informatika Dan Komputer FTI UNSA. 